地域在住高齢者における股関節開排筋力および

大腿四頭筋筋力と身体機能との関連

\title{
The relationship between the hip abductor strength on flexion/ quadriceps femoris muscle strength and each physical function in community-dwelling elderly people
}

\author{
松本 典久 ${ }^{1)}$, 村田 伸 ${ }^{2)}$, 白岩加代子 ${ }^{2)}$, 合田 明生 ${ }^{2)}$ \\ 安彦 鉄平 ${ }^{2)}$, 中野 英樹 ${ }^{2)}$, 堀江 淳 ${ }^{2)}$
}

Norihisa Matsumoto, Shin Murata, Kayoko Shiraiwa, Akio Goda

Teppei Abiko, Hideki Nakano, Jun Horie

\begin{abstract}
要旨： 本研究は，股関節開排筋力および大腿四頭筋筋力と各種身体機能との関連を分析 し, 股関節開排筋力測定の有用性を検討することを目的とした。地域在住高齢者 274 名 (男 性52名, 女性222名, 平均年齢74.4 55.2 歳）を対象に, 股関節開排筋力, 大腿四頭筋筋力, 足趾把持力, 握力, 上体起こし回数, 長座体前屈距離, 開眼片足立ち保持時間, Timed Up \& Go test (TUG), 筋肉量, 下肢筋肉量を計測した。分析の結果, 股関節開排筋力と大腿 四頭筋筋力は，男性ではともに筋肉量と下肢筋肉量を除くすべての項目と有意な相関が認 められ，女性では長座体前屈距離と開眼片足立ち保持時間を除くすべての項目と有意な相 関が認められた。これらの知見から，股関節開排筋力測定は大腿四頭筋筋力と同様に，高 齢者における体力全般を表す指標となりうることが示された。
\end{abstract}

キーワード：地域在住高齢者，股関節開排筋力，大腿四頭筋筋力

\begin{abstract}
The relationship between the hip abductor strength on flexion/quadriceps femoris muscle strength and each physical function parameter was analyzed to confirm the usefulness of measuring the former. The hip abductor strength on flexion, quadriceps femoris muscle strength, toe grip strength, hand grip strength, number of sit-ups, sit-andreach test score, duration of standing on one leg with the eyes open, Timed Up and Go test (TUG) score, whole-body muscle mass, and leg muscle mass were measured in 274 community-dwelling elderly people (male:52, female:222, mean age:74.4 45.2 ). In the male group, both the hip abductor strength on flexion and quadriceps femoris muscle strength were significantly correlated with all physical function parameters, excluding the wholebody and leg muscle masses. In the female group, the 2 muscle strengths were significantly correlated with all physical function parameters, excluding the sit-and-reach test score and duration of standing on one leg with the eyes open. Based on the results, the hip abductor strength on flexion may be as useful as the quadriceps femoris muscle strength as an overall physical fitness index for elderly people.
\end{abstract}

Key words: community-dwelling elderly people, hip abductor strength on flexion, quadriceps femoris muscle strength

受付日：2020年 1 月31日，採択日：2020年 3 月 4 日

小倉リハビリテーション学院理学療法学科

Department of Physical Therapy, Kokura Rehabilitation School

テ800-0206 福岡県北九州市小倉南区暮原東 2-2-10

2-2-10 Kuzuharahigashi Kokuraminami-ku Kitakyushu-city, Fukuoka 800-0206,Japan.

TEL : 093-473-8005 E-mail : matsu@kokura-reha.jp

2) 京都栭大学健康科学部

Faculty of Health Science,Kyoto Tachibana University 


\section{I . 緒 言}

一般的な筋力評価法として最も普及しているのは徒 手筋力検査法 (Manual Muscle Testing;MMT) ${ }^{1)}$ であ る。しかし，MMT の段階 0 〜 3 は基準が明確であり 判定が容易であるが，MMT の段階 4 〜 5 は，基準が 主観的要素を含み不明確であるため判定が難しい。主 観的評価よりも客観的に筋力を評価することが求めら れるが，等速性筋力測定機器は信頼性に優れるものの 高価であり，操作法も簡便とはいえない。そこで近年 では，ハンドヘルドダイナモメーター (Hand-Held Dynamometer;HHD）を用いた筋力評価が実施されるよ うになった。

なかでも，HHD をベルトで固定して大腿四頭筋筋 力を評価する方法 ${ }^{2}$ が普及している。加藤ら ${ }^{2}$ が報告し たベルトで固定する大腿四頭筋筋力測定は，健常成人 を対象とした場合，級内相関係数 (Intraclass Correlation Coefficient;ICC）は0.937であり，高い再現性を 認めた。また, 立ち上がり能力 ${ }^{3)}$ や歩行能力 ${ }^{4)}$, バラン ステスト ${ }^{5,6)}$ との間に有意な相関を認めることが報告さ れている。このように，大腿四頭筋筋力測定は信頼性 と妥当性に優れた下肢筋力の評価法として広く認識さ れているが，膝関節疾患で痛みのある患者では，本来 有する筋力を発揮できないとの報告 ${ }^{7}$ もある。とくに， 膝関節に疼痛を伴う変形性膝関節症は罹患率の高い疾 患であり，見過ごすことのできない課題である。よっ て, 膝関節以外を対象とした簡便な筋力測定法の開発 が望まれる。

大腿四頭筋と同様に，抗重力筋である股関節伸展筋 や股関節外転筋も立位姿勢保持に重要な役割を果たし ている ${ }^{8)}$ 。また，股関節周囲筋は下肢の運動器疾患に おける筋力低下 ${ }^{9,10)}$ や, 転倒 ${ }^{11)}$ との関連も報告されて いる。しかし，股関節周囲筋の筋力は，その定量的測 定方法が確立されていないのが現状である。

そこで，松本ら ${ }^{12)}$ は，HHD を使用した股関節開排 筋力の測定法を考案した。股関節開排筋力は，大殿筋， 中殿筋, 大腿筋膜張筋, 縫工筋が関与しており, 股関 節周囲筋の総和的筋力を表す ${ }^{13)}$ 。股関節開排筋力は, 健常成人男性を対象に検討した結果, 高い再現性(ICC $=0.912 ）$ を認め ${ }^{12)}$, 大腿四頭筋筋力との間に有意な 相関が認められた ${ }^{12,14)}$ 。しかし, 股関節開排筋力と身 体機能の関連について詳細な検討は行われていない。 股関節開排筋力が他の筋力や歩行能力, バランス能力 との間に関連を認めることになれば，股関節開排筋力 における筋力評価法としての妥当性を明らかにできる
と考えた。

そこで本研究は，地域在住高齢者を対象に股関節開 排筋力および大腿四頭筋筋力と身体機能との関連を分 析し，股関節開排筋力測定の臨床的有用性を検討した。

\section{II. 対 象}

対象者は，A市が主催する体力測定会に参加した地 域在住高齢者274名とした。対象者のうち男性高齢者 は52名 (平均年齢75. $1 \pm 5.5$ 歳, 平均身長 $164.7 \pm 5.9 \mathrm{~cm}$, 平均体重 $61.6 \pm 7.3 \mathrm{~kg}$ ), 女性高齢者は 222 名（平均年 齢74. $3 \pm 5.2$ 歳, 平均身長 $151.6 \pm 5.0 \mathrm{~cm}$, 平均体重 50.6 $\pm 6.9 \mathrm{~kg}$ ）であった。対象者は自家用車や自転車，あ るいは徒歩によって体力測定会に参加できる程度に自 立した高齢者であった。

対象者には本研究の趣旨と内容を十分に説明した。 測定結果は厳重に管理し研究以外で使用しないこと, 研究への参加は自由であり，不参加であっても不利益 にならないことを合わせて説明した。その上で書面上 にて研究参加の同意を得た。なお，本研究は京都橘大 学研究倫理委員会の承認（承認番号18-26）を得て実 施した。

\section{III. 方 法}

測定項目は，股関節開排筋力，大腿四頭筋筋力，足 趾把持力, 握力, 上体起こし回数, 長座体前屈距離, 開眼片足立ち保持時間, TUG, 筋肉量, 下肢筋肉量 とした。

股関節開排筋力の測定には，HHD（ミュータス F 1 ：アニマ社） 2 個と付属の固定用ベルト 1 本を使用 した。対象者を床に敷いたマットの上で背臥位とし， 股関節約 $45^{\circ}$ 屈曲位, 膝関節約 $90^{\circ}$ 屈曲位, 足底をマッ トに着けた肢位とした。センサーパッドを $90^{\circ}$ 屈曲し た膝関節の両外側に 1 個ずつ入れベルトで固定した

（図 1 ）。「足首を揃えたまま膝を力いっぱい開いてく ださい。」と指示し，約 5 秒間の等尺性最大筋力を測 定した（図 2 ）。測定回数は 1 回とし, 左右の測定值 を合算した值を分析に用いた。

大腿四頭筋筋力の測定は，加藤らの方法 ${ }^{2}$ に準じ, HHD（ミュータスF1：アニマ社製）1個と固定用 ベルト 1 本を使用した。対象者を椅子座位下腿下垂位 とし，下腿後方の支柱と計測側の下腿遠位部を取り巻 くように固定用ベルトを装着した。センサーパットを 下腿遠位部に固定し，膝関節伸展運動を行った際の等 尺性最大筋力を測定した。左右それぞれ2 回ずつ測定 


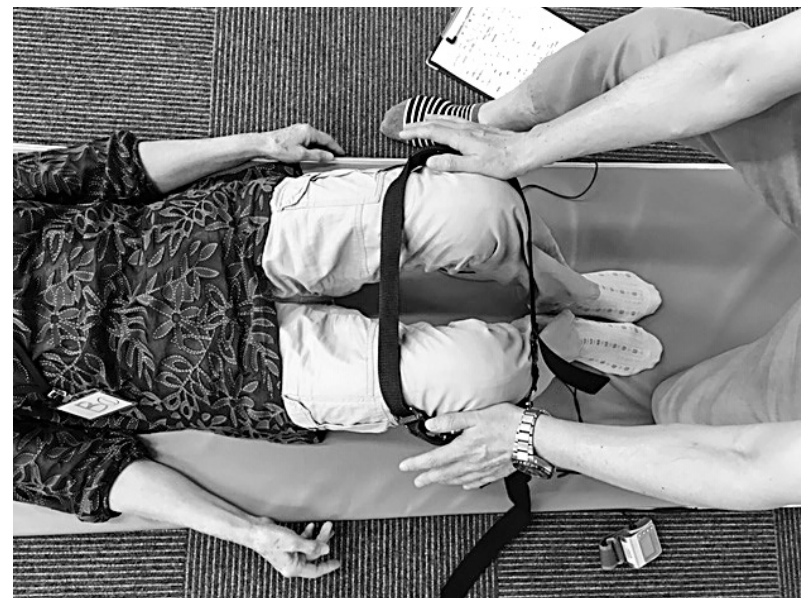

図 1 股関節開排筋力測定におけるべルトと HHD

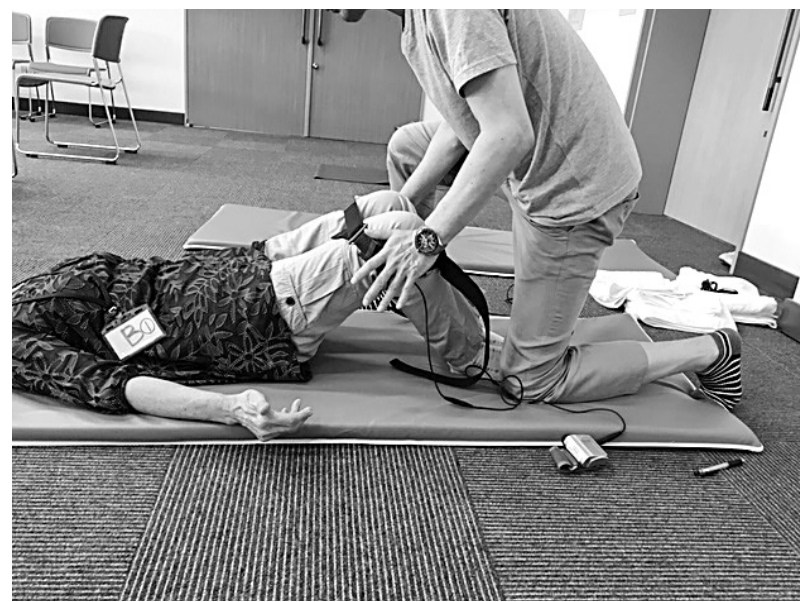

図 2 股関節開排筋力測定

\section{し，最大值を分析に用いた。}

足趾把持力の測定には, 足趾握力測定值 (竹井社製) を使用した。測定肢位は端坐位とした。股関節 $90^{\circ}$ 屈 曲位，膝関節 $90^{\circ}$ 屈曲位とし，左右それぞれ 2 回ずつ 測定し，最大值を分析に用いた。

握力の測定には，デジタル握力計（竹井社製）を使 用した。測定肢位は立位とした。両上肢を体側に垂ら した肢位で握力計を把持する際の等尺性最大筋力を測 定した。左右それぞれ 2 回ずつ測定し, 各側最大值の 平均値を分析に用いた。

上体起こし回数の測定は, 対象者を床に敷いたマッ トの上で背臥位，膝関節約 $90^{\circ}$ 屈曲位として実施した。 両腕を胸の前で組み，30秒間で肘が大腿部につくまで 上体を起こす回数を測定した。

長座位前屈距離の測定には, デジタル式長座位前屈 測定器 (竹井社製) を使用した。対象者を後頭部と背 部を壁につけた長座位で両膝は伸展位とした。両肘関 節伸展位で測定器に手を置き，できるだけ前方へ身体
を前に屈曲して測定した。2 回測定し，最大值を分析 に用いた。

開眼片足立ち保持時間は，対象者を開眼片足立ち位 として，その姿勢を保持できる時間を測定した。120 秒を上限として左右 2 回ずつ計測し，その最長時間を 分析に用いた。両上肢はかるく体側につけること， 2 $\mathrm{m}$ 前方の視線と同じ高さを注視することなどの条件 の下で実施した。

TUG は，対象者を肘かけのない高さ約 $40 \mathrm{~cm}$ の椅 子上座位として測定を開始した。立ち上がり， $3 \mathrm{~m}$ 前方のコーンまでを往復し，再び椅子に座るまでの時 間を測定した。測定は，できるだけ速く往復するよう に口頭で指示した ${ }^{15)}$ 。測定回数は 2 回とし, 最速值を 分析に用いた。

筋肉量の測定には，ポータブル体成分分析装置 Inbody430（バイオベース社製）を使用した。対象者は 両手で電極を把持し装置上に裸足で立位となり，微弱 な通電に伴う電気抵抗計測により身体組成が測定され た。算出された全身の筋肉量と下肢筋肉量を分析に用 いた。

統計学的分析は, SPSS22. OJ for windows を使用し た。股関節開排筋力および大腿四頭筋筋力と他の測定 值との関係についてピアソンの相関係数を求めて検討 した。有意水準は 5 \%とした。

\section{N. 結 果}

各測定值の平均と標準偏差を表 1 に示す。男性にお いて, 股関節開排筋力および大腿四頭筋筋力との間に 有意な相関を認めた項目は, 足把持力, 握力, 上体お こし回数, 長座体前屈距離, 開眼片足立ち保持時間, TUGであり，筋肉量と下肢筋肉量を除くすべての測 定項目であった。股関節開排筋力は筋肉量と下肢筋肉 量との間に有意な相関を認めたが，大腿四頭筋筋力は これらの項目との間に有意な相関を認めなかった（表 2 )。

女性において，股関節開排筋力および大腿四頭筋筋 力との間に有意な相関を認めた項目は，足把持力，握 力, 上体おこし回数, TUG, 筋肉量, 下肢筋肉量で あり，長座体前屈距離と開眼片足立ち保持時間を除く 全ての項目であった。大腿四頭筋筋力は開眼片足立ち 保持時間との間に有意な相関を認めたが，股関節開排 筋力は有意な相関を認めなかった。股関節開排筋力お よび大腿四頭筋筋力はともに, 長座体前屈距離との間 に有意な相関を認めなかった。(表 3 )。 
表 1 男性高齢者および女性高齢者の測定結果

\begin{tabular}{lll}
\hline & $\begin{array}{c}\text { 男性高齢者 } \\
(\mathrm{n}=52)\end{array}$ & $\begin{array}{c}\text { 女性高齢者 } \\
(\mathrm{n}=222)\end{array}$ \\
\hline 股関節開排筋力 $(\mathrm{kg})$ & $35.5 \pm 7.9$ & $25.3 \pm 5.5$ \\
大腿四頭筋笳力 $(\mathrm{kg})$ & $29.5 \pm 6.9$ & $19.5 \pm 4.3$ \\
足趾把持力 $(\mathrm{kg})$ & $11.1 \pm 4.8$ & $7.4 \pm 3.0$ \\
握力 $(\mathrm{kg})$ & $34.8 \pm 5.5$ & $22.8 \pm 4.1$ \\
上体起こし回数（回） & $11.7 \pm 7.6$ & $9.0 \pm 6.6$ \\
長座体前屈 $(\mathrm{cm})$ & $31.7 \pm 10.7$ & $36.9 \pm 8.5$ \\
開眼片脚立ち（秒） & $35.3 \pm 33.5$ & $32.0 \pm 29.0$ \\
TUG（秒） & $5.6 \pm 1.4$ & $5.7 \pm 1.0$ \\
筋肉量（kg） & $45.1 \pm 4.7$ & $33.0 \pm 3.4$ \\
下肢筋肉量 $(\mathrm{kg})$ & $15.5 \pm 2.0$ & $10.6 \pm 1.5$ \\
\hline
\end{tabular}

表 2 股関節開排筋力および大腿四頭筋筋力と身体機能と の相関分析（男性： $\mathrm{n}=52$ )

\begin{tabular}{lcc}
\hline & 股関節開排筋力 & 大腿四頭筋筋力 \\
\hline 大腿四頭筋筋力 & $0.40^{* *}$ & \\
足趾把持力 & $0.46^{* *}$ & $0.52^{* *}$ \\
握力 & $0.57^{* *}$ & $0.36^{* *}$ \\
上体起こし回数 & $0.33^{*}$ & $0.54^{* *}$ \\
長座体前屈距離 & $0.33^{*}$ & $0.42^{* *}$ \\
開眼片脚立ち保持時間 & $0.39^{* *}$ & $0.46^{* *}$ \\
TUG & $-0.40^{* *}$ & $-0.50^{* *}$ \\
筋肉量 & $0.49^{* *}$ & 0.25 \\
下肢筋肉量 & $0.31^{*}$ & 0.19 \\
\hline
\end{tabular}

${ }^{*}: \mathrm{P}<0.05,{ }^{* *}: \mathrm{P}<0.01$

表 3 股関節開排筋力および大腿四頭筋筋力と身体機能と の相関分析（女性： $\mathrm{n}=222 ）$

\begin{tabular}{lcc}
\hline & 股関節開排筋力 & 大腿四頭筋筋力 \\
\hline 大腿四頭筋筋力 & $0.45^{* *}$ & \\
足趾把持力 & $0.34^{* *}$ & $0.40^{* *}$ \\
握力 & $0.40^{* *}$ & $0.46^{* *}$ \\
上体起こし回数 & $0.37^{* *}$ & $0.43^{* *}$ \\
長座体前屈距離 & 0.13 & 0.14 \\
開眼片脚立ち保持時間 & 0.13 & $0.31^{* *}$ \\
TUG & $-0.34^{* *}$ & $-0.41^{* *}$ \\
筋肉量 & $0.39^{* *}$ & $0.45^{* *}$ \\
下肢筋肉量 & $0.38^{* *}$ & $0.41^{* *}$ \\
\hline
\end{tabular}

${ }^{*}: \mathrm{P}<0.05,{ }^{* *}: \mathrm{P}<0.01$

\section{V，考 察}

股関節開排筋力と大腿四頭筋筋力は，男女ともに， 足把持力，握力，上体おこし回数との間に有意な相関 を認めた。これらはすべて上下肢と体幹の筋力に関連 する項目である。大腿四頭筋筋力がこれらの項目との
間に相関を認め，高齢者の全身的な体力を表すことは 既に報告 ${ }^{16,17)}$ されており, 先行研究と同様の結果となっ た。股関節開排筋力は股関節の筋力であり ${ }^{13)}$ 元来は局 所的な筋力であるが，全身の筋力と関連することが示 された。股関節開排筋力は，下肢のみならず体幹や上 肢を含めた全身の筋力を反映する可能性が示された。

また, 股関節開排筋力と大腿四頭筋筋力は, 男女と もにTUGとの間に有意な相関を認めた。股関節開排 運動は，足部を接地しての股関節伸展，外転，外旋の 複合運動と捉えることができ ${ }^{18)}$, 股関節伸展筋や外転 筋などの股関節周囲筋が関与する ${ }^{13)}$ 。股関節周囲筋が, TUGにおける立ち上がりや歩行, 方向転換の動作時 に骨盤を安定させ，結果として TUGが短縮したと考 えられる。大腿四頭筋筋力が TUGとの間に相関を認 めることは報告されている ${ }^{6}$ が，股関節開排筋力も同 様に，TUGとの間に有意な相関を認めた。股関節開 排筋力は, 大腿四頭筋筋力と同様に, 歩行能力やバラ ンス能力と関連する可能性が示された。

股関節開排筋力と大腿四頭筋筋力は，男性において 開眼片足立ち保持時間との間に有意な相関を認めた。 しかし，女性においては，大腿四頭筋筋力は，開眼片 足立ち保持時間との間に有意な相関を認めたものの， 股関節開排筋力は相関を認めなかった。股関節開排筋 力に関与する股関節伸展筋や股関節外転筋 ${ }^{13)}$ は, 片脚 立位時における骨盤の安定に寄与すると考えられる。 その一方で，地域在住女性高齢者における片脚立位時 間は足把持力の関連は大きいものの，下肢の主要な筋

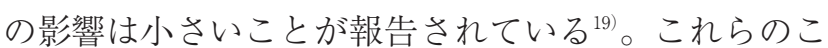
とが関連し，女性において股関節開排筋力は，開眼片 足立ち保持時間との間に有意な相関を認めなかったも のと推察した。

股関節開排筋力と大腿四頭筋筋力は，男性において 長座体前屈距離との間に有意な相関を認めたが，女性 においては認めなかった。柔軟性の評価である長座体 前屈距離において，女性では筋力の影響を受けにくい ことが報告 ${ }^{16,20)}$ されている。今回の結果は先行研究と 同様の結果となった。

男性において，股関節開排筋力は身体組成の測定項 目である筋肉量と下肢筋肉量との間に有意な相関を認 めたが，大腿四頭筋筋力はこれらとの間に有意な相関 を認めなかった。筋肉量と筋力は比例関係にあるとさ れ ${ }^{21,22)}$, 先行研究と矛盾する結果となった。筋力低下 を伴わず䇗肉量のみが低下した状態をプレサルコペニ アと称し，軽症段階のサルコペニアとして病期分類さ 
れている ${ }^{23)}$ 。サルコペニアは, 速筋（type II）線維の 選択的萎縮を伴う ${ }^{24)}$ 。大腿四頭筋は速筋（type II）線 維優位の筋とされ ${ }^{25)}$, 加齢に伴う筋肉量変化の影響が 大きいと考えられる。一方, 筋肉量低下を伴わない筋 力低下を呈するダイナペニアの概念も提唱されてい る26)。プレサルコペニアやダイナペニアの存在が本研 究結果に影響したか不明であるが, 大腿四頭筋筋力と 筋肉量との間に相関が認められなかった理由の一つか もしれない。高齢者では加齢と筋力, 筋肉量との関係 において必ずしも一貫した結論を見ておらず，今後の 課題と考えられる。

高齢者の主訴で最も多いのは腰痛と膝関節痛27)であ る。今回は腰痛や膝関節痛の調査は行えていないが, 本研究対象例にも腰痛や膝関節痛のある者が相当数い たことが予測され，そのことが影響したのかもしれな い。

女性において，すべての項目で股関節開排筋力との 相関係数が大腿四頭筋筋力より低值となった。また, 女性における股関節開排筋力の相関倸数は, 概ね男性 より低值であった。その理由として，女性は股関節を 開く方向に力を入れることに心理的な抵抗があり，十 分に筋力が発揮できなかった可能性が挙げられる。女 性の羞恥心による心理的な性差は, 股関節開排筋力測 定に扮ける問題点と考えられる。

これらの知見より, 地域在住高齢者に扔いて, 上下 肢や体幹の筋力, 歩行能力, バランス能力が高いほど 股関節開排筋力も高いことが明らかとなり，股関節開 排筋力の妥当性が示された。股関節開排筋力測定は, 大腿四頭筋筋力と同様に, 高齢者の全身的な体力を表 す簡便な粗大筋力評価法として, 臨床応用できること が示唆された。ただし，本研究における股関節開排筋 力および大腿四頭筋筋力は, ともに身体機能との間の 相関係数は概ね 0.5 以下であり, 相関が強いとは言い 難い。これには，高齢者に多い腰痛や膝関節痛などが 影響して筋力が発揮できなかった可能性も考えられる。 今後は, 疼痛に着目した検証が必要である。

\section{引用文献}

1) Helen J. Hislop, Date Avers, Marybeth Brown : 新 ·徒手 筋力検查法 原著 第 9 版. 協同医書出版, 東京, 2017, 7 .

2）加藤宗規, 山崎裕司, 柊 幸伸・他：ハンドヘルドダイナ モメーターによる等尺性膝伸展筋力の測定－固定用ベルト の使用が検者間再現性に与える影響。総合リハ, 2001，29 (11) : 1047-1050.

3) 大森圭貢, 横山仁志, 青木詩子 ·他：高齢患者における等
尺性膝伸展筋力と立ち上がり能力の関連. 理学療法 学, 2004, 31(2) : 106-112.

4）西島智子, 小山理惠子, 内藤郁奈・他：高龃患者における 等尺性膝伸展筋力と歩行能力との関係. 理学療法科 学, 2004, 19(2): 95-99.

5）村田伸, 大田尾浩, 村田潤 - 他：虚弱高齢者用10秒椅子立 ち上がりテスト（FrailCS-10）の有用性の検討. 理学療法 科学, 2010, 25(3): 431-435.

6) 村田 伸, 大田尾浩, 村田 潤 - 他：虚弱高齢者における Timed Up and Go Test, 歩行速度, 下肢機能との関連. 理学療法科学, 2010, 25(4) : 513-516.

7）村田 伸, 甲斐義浩, 大田尾浩 - 他：女性高齢者の膝関節 痛と大腿四頭筋筋力との関連. 理学療法科学, 2009, 24 (4) : 499-503.

8）中村隆一, 齋藤 宏, 長崎 浩: 基礎運動学第 6 版. 医歯 薬出版, 東京, 2011：348-349.

9) Fredericson M, Cookingham C L, Chaudhari A M, et al.: Hip abductor weakness in distance runners with iliotibial band syndrome. Clinical Journal of Sport Medicine, 2000, 10(3): 169-175.

10) Brindle T J, Mattacola C, McCrory J:Electromyographic changes in the gluteus medius during stair ascent and descent in subjects with anterior knee pain.Knee Surgery, Sports Traumatology,Arthroscopy, 2003, 11(4): 244-251.

11）田井中幸司, 青木純一郎：在宅高齢女性の転倒経験と体力. 体力科学, 2007, 56:279-286.

12）松本典久, 村田 伸, 中林紘二・他：ハンドヘルドダイナ モメーターによる股関節開排筋力の評価. 西九州リハビリ テーション研究, 2012, 5 : 59-62.

13）松本典久, 村田 伸, 山田道廣 : 股関節開排運動における 股関節周囲筋の筋活動. ヘルスプロモーション理学療法研 究, 2020, 9 (4)：161-165.

14）松本典久, 村田 伸, 上城憲司・他：地域女性高齢者を対 象とした股関節開排筋力測定の再現性と妥当性の検討. ルスプロモーション理学療法研究, 2012, 2 (3) : 91-95.

15）島田裕之, 古名丈人, 大渕修一・他：高齢者を対象とした 地域保健活動における Timed Up \& Go Testの有用性. 理 学療法学, 2006, 33(3) : 105-111.

16）池田 望, 村田 伸, 大田尾浩 - 他：地域在住女性高齢者 の握力と身体機能との関係. 理学療法科学, 2011, 26(2) : 255-258.

17）村田 伸, 大田尾浩, 村田 潤 - 他：地域在住高齢者の上 体おこしの可否と身体および心理機能との関連. 理学療法 科学, 2010, 25(1): 115-119.

18）森實徹, 加納一則, 相川和久 - 他：屈膝臥位における開排 運動時の下肢筋々活動. 理学療法学, 1998, 25(2) : 534 .

19）村田 伸, 大山美智江, 太田尾浩 - 他：地域在住高齢者の 開眼片足立ち保持時間と身体機能との関連. 理学療法科 学, 2008, 23(1): 79-83.

20）樋口雅俊, 岡田 明, 久本誠一 - 他 : 日本人の体力測定結 果に関する考察—健常者を対象とした測定結果に基づく報 告. 日本生理人類学会誌, 2008, 3(2)：115-124.

21）甲斐義浩, 藤野英己, 村田 伸 - 他：身体組成と上·下肢 筋力および四肢周径に関する研究. 理学療法科 
学, 2008, 23(2) : 241-244.

22）甲斐義浩, 村田 伸, 大田尾浩 - 他：地域在住高齢者女性 の身体組成と身体機能との関係. 理学療法科学, 23(6): 811-815.

23) Cruz-Jentoft AJ, Baeyens JP, Bauer JM, et al.: European consensus on definition and diagnosis:Report of the European Working Group on Sarcopenia in Older People.Age snd Ageing, 2010, 39(4): 412-423.

24）酒井義人：骨量 - 筋量減少と虚弱. Medical Rehabilitation, 2014, $170: 33-39$.

25）猪俣高志：理学療法のための筋の基礎知識. 埼玉理学療 法, 2004, 11: 2-11.

26) Clark B C,Manini T M:What is dynapenia?. Nutrition, 2012, 28(5): 495-503.

27）大㴊修一, 杉本 諭: 高齢者の痛みが活動・参加に及ぼす 影響と理学療法. 理学療法ジャーナル, 2008, 42(2)：123 -129 . 